\title{
RURAL DEVELOPMENT IN EUROPEAN UNION POLICY
}

Malgorzata Michalcewicz-Kaniowska ${ }^{1}, \mathrm{PhD}$; Malgorzata Zajdel ${ }^{2}$, PhD

1,2UTP University of Science and Technology in Bydgoszcz, Poland, Faculty of Management

\begin{abstract}
When in 1958, under the Treaty of Rome, the Common Market was established, agriculture of the six founding member states was strongly influenced by state interventionism. In order to include agricultural production in the free movement of goods, while maintaining public interventionism in the agricultural sector, national intervention mechanisms incompatible with the free movement principle had to be abolished and transferred to the Community level. Actions in this direction led to defining the objectives of the Common Agricultural Policy (CAP) as the first common policy established in the framework of the European Economic Community. Over time, it turned out that market mechanisms are far from sufficient and should be supplemented by structural instruments pertaining to the need for rural development. The aim of the European Union's rural development policy, which is the second pillar of the CAP, is to support the rural areas of the EU and to meet numerous economic, environmental and societal challenges. Its greater flexibility (compared to Pillar I) enables regional, national and local authorities to develop their own rural development programmes based on European mechanisms. In contrast to Pillar I, which is financed wholly by the EU, programmes under Pillar II are co-financed from EU funds and national, regional or local funds. The purpose of this article is to analyse the fundamental determinants of the rural development policy, its increasing role in the EU's economic strategy and the prospects for its further functioning. While preparing the text was used a method of critical reference to the literature of the subject of research, as well as a method of analyzing secondary sources, including studies describing substantive issues concerning the broadly understood agricultural policy of the European Union.
\end{abstract}

Key words: Common Agricultural Policy, rural areas, Multiannual Financial Framework, EU budget. JEL code: $013, \mathrm{Q} 18$.

\section{The shaping of the EU' Common Agricultural Policy}

The year 1962 is considered to be the beginning of the Common Agricultural Policy (CAP) of the European Economic Community (the EU's predecessor), created five years prior to that. Its fundamental objective was to provide the citizens of the Member States with affordable food while ensuring decent remuneration for farmers and thus an adequate standard of living. An important premise of the actions taken was the need to maintain food self-sufficiency, which was the aftermath of serious shortages of agricultural products after the end of World War II.

Among the first decisions were the introduction of a common pricing policy and a common organisation of agricultural markets as well as the launching of a support mechanism for agricultural incomes through guaranteed prices. The original objectives of the CAP were quickly achieved, which was viewed as evidence of its effectiveness; however, a phenomenon appeared, namely the increasing overproduction. Farms were becoming increasingly efficient, so that they began producing more food than actually needed. The surpluses were stored in warehouses, whose capacities soon proved insufficient. A wide array of measures was then introduced to better adjust production levels to market needs.

In the process of CAP evolution, a major breakthrough was the so-called MacSharry reform, implemented in the years 1992-1996. It consisted, inter alia, in the gradual lowering of intervention prices for certain agricultural products (mainly grain and beef) and in the introduction of compensatory payments for farmers. These payments were to compensate them for income losses resulting from the reductions in agricultural prices. Obtaining the aforementioned subsidies depended on the reduction of the crop areas and decreasing the intensity of animal production. The compensatory payments were later referred to as direct payments. For the first time, so-called accompanying measures were introduced, where the EU financed 50-75 \% (depending on the region) 
of the costs of programmes aimed at: afforestation, encouraging farmers to use production methods that protect the environment and the quality of rural areas as well as supporting the transition of farmers to early retirement and the transfer of farms to improve the agrarian structure (Komisja Europejska, 2014).

As part of the 1999 reform, the intervention buying-in prices for grain, beef, powdered milk, butter was reduced, and the scope of intervention in the beef market was limited. Farmers were compensated for the cuts in the intervention prices by increasing direct payments. As a result, the range of aid instruments for farmers in less-favoured regions was expanded and the need to support rural development was emphasised. In June 2003, the next reform of the CAP, defined as a fundamental one and aimed at increasing the competitiveness of Community agriculture as well as improving the quality of food, was agreed upon by the agriculture ministers of EU countries in Luxembourg. The provisions of the Council of the EU of 26 June 2003 determined the shape of the CAP in the years 2007-2013. The basic elements of the reform were: the separation of direct payments from actual production (decoupling); linking direct payments with the obligation to meet certain standards related to environmental protection, plant and animal health and good treatment of animals (cross-compliance); the reduction of the scale of direct payments for farms (so-called modulation) and the allocation of resources thus obtained for rural development; the introduction of the mechanism of the so-called financial discipline, consisting in the reduction of direct payments in the event of exceeding the CAP spending ceiling; a further increase in the scope and level of support for rural development (Hardt, 2003).

The CAP is the first of the common EU policies that is financed entirely from its budget. It was recognised that achieving a common goal would be more effective if the resources from the budget were mobilised than if the individual Member States acted on their own. This was supported by the existence of a single and constantly developing European market of agricultural products, where farmers can be guaranteed fair conditions of competition on the EU internal market (thanks to a common approach to supporting agriculture), and (based on the regulations of the customs union) on global markets.

\section{New challenges facing the CAP}

As early as in the 1970s, the conviction that agriculture cannot be reduced to the productive sphere only, i.e. the commercial one, and that it fulfils important sociocultural and environmental functions, began to solidify. This point of view resulted, inter alia, from such phenomena as the growing problem of depopulation and marginalization of large rural areas, a decline in competitiveness compared to urban centres or natural environment degradation. This made it necessary to undertake multidirectional actions to improve the social and technical infrastructure, to create non-agricultural employment opportunities and to maintain high-quality natural resources in rural areas. The importance of this problem is evidenced by the fact that over half of the population of EU member states live in rural areas, which cover $90 \%$ of its territory (in Poland, rural areas constitute $93.1 \%$ of the territory of the country, which is inhabited by $39.2 \%$ of the total population). Agriculture and forestry are still of key importance in the field of land use and natural resource management in rural areas in the $\mathrm{EU}$, and also serve as a platform enabling the diversification of the economy in rural communities. The necessity of strengthening the EU rural development policy became a general priority of the European Union, which was clearly expressed in the conclusions of the European Council in June 2001: 'In recent years, the European agricultural policy has put less 
emphasis on market mechanisms and, thanks to the use of targeted support measures, it has become more geared towards satisfying the growing needs of the general public in terms of food safety and quality, product differentiation, animal welfare, environmental quality as well as nature and landscape protection '(Polityka UE, 2008).

The EU has not yet developed a definition of rural areas that could become not only the basis for theoretical analyses but also the starting point for formulating a coherent concept of their development. The standards found in the Council Decision of 20 February 2006 on the Community strategic guidelines for rural development for the period 2007-2013 (Decyzja Rady, 2006) can be regarded as the most useful. The areas where the rural population exceeds $50 \%$ or those inhabited by less than 150 people/km2 are considered rural areas. A significant classification proposed by the OECD is worth mentioning; it divides regions into:

1) predominantly rural regions, where over $50 \%$ of inhabitants live in administrative units with population density less than 150 people/km2,

2) significantly rural regions, where the share of population inhabiting administrative units with population density lower than 150 people/km2 is between $15 \%$ and $50 \%$ (Wieliczko, 2006),

3) predominantly urban regions, where the rural community constitutes less than $15 \%$.

A simplified definition has been adopted in the Rural Development Programme prepared by the European Commission and the Ministry of Agriculture and Rural Development of the Republic of Poland for the years 2014-2020: 'rural areas are terrains located outside the city administrative boundaries, i.e. rural communes or rural parts of urban-rural communes' (PROW, 2018).

\section{Pillar II of the EU's Common Agricultural Policy}

Agenda 2000 was of key importance in the EU discussion on the need for rural development. Its adoption was directly related to the prospect of accession for eight countries located in the Central and Eastern Europe region as well as Cyprus and Malta (Oleszko-Kurzyna, 2010). The lower level of development of the agricultural sector and rural areas in these countries posed new challenges to the EU. It was not only about the budgetary production support, but also about non-productive functions performed by agriculture, i.e. those with regard to culture, the landscape etc. Civilisational changes altered European countryside, which became not only a place for agricultural production but also for living or non-agricultural business activities. Increasing attention was paid to actions for the protection of the natural environment, food security, animal welfare or so-called multifunctional and sustainable agriculture.

The main contribution of Agenda 2000 was the extension of the impact of the CAP with the Pillar II, which included structural measures for the multifunctionality of agriculture and for rural development (Drugi filar WPR, 2019). In addition to the support for agri-environmental and afforestation activities or structural retirement schemes, assistance in, among other things, modernising farms, diversification into non-agricultural activities, adjusting farms to EU environmental standards or improving infrastructure in rural areas, was provided. Since that time, the CAP has ceased to be a typical sectoral policy, aimed solely at the development of agriculture, and it has become an integrated policy for rural development (agro rural policy).

As part of the division of tasks concerning the management of individual rural development programmes between the European Commission and the Member States, the latter designate a managing authority, an accredited paying agency and a certification body. Additionally, they provide and disseminate information on operations subject to co-financing. Each country establishes a 
monitoring committee that ensures the effective implementation of the programme, while the authority which manages a given programme submits an annual report on its implementation to the Commission.

The reform of the CAP has been forced by contemporary challenges, which include food security, climate change, sustainable economic growth and creating employment opportunities in rural areas. It is also better adjusted to the expectations of the people: direct payments will be more fair and environment-friendly. Farmers will have a stronger position in the food supply chain, and the new CAP will be more targeted, efficient and transparent. It should also be mentioned that the new CAP supports market-oriented agriculture (for example, without export subsidies, which have been withdrawn in recent years). In 2011, agricultural products accounted for as much as $7 \%$ of EU exports, which is equivalent to the amount exceeding EUR 100 billion - more than cars or pharmaceutical products. The CAP is, therefore, an important factor that promotes employment as well as smart and sustainable economic growth that prevents social exclusion. For 50 years, the CAP has become a truly European policy of strategic importance and, what is more, it is a genuinely Community policy.

The Rural Development Programme within the MFF 2014-2020 consists of 16 measures, most of which have been divided into sub-measures. It is worth briefly presenting a few of them (PROW, 2018).

Measure: 'Knowledge transfer and information actions' - two sub-measures: 'Vocational training and skills acquisition' and 'Demonstrations and information activities' (beneficiaries: public advisory entities, scientific institutions and universities, agricultural and forestry-related schools as well as entities conducting training activities; aimed at out-of-school education of agricultural producers and rural inhabitants, mainly through courses and training which raise the level of knowledge and promote innovations in the field of agriculture and forestry),

Measure: 'Quality schemes for agricultural products and foodstuffs' - two sub-measures: 'Support for new participants of food quality schemes' and 'Support for carrying out information and promotional activities'. The objective: introducing high-quality agricultural products and foodstuffs to the market (beneficiaries: a farmer or an entity created by at least two producers of agricultural products or foodstuffs, who work under quality schemes),

Measure: 'Investments in physical assets' - three sub-measures: 'Modernisation of agricultural holdings' (the objective: development of cow milk, beef cattle and piglets production and also operations focused on new innovative technologies, increasing the production scale and improving production quality); the sub-measure 'Processing and marketing of agricultural products' (the objective: processing and placing agricultural products on the market at the level of wholesale trade - the beneficiary: an entity with a registered activity in the field of processing or placing agricultural products on the market, which runs a micro, small or medium sized enterprise, or either a farmer or a farm household member subject to full social insurance for farmers); the sub-measure 'Land consolidation' (the objective: improvement in the area structure of agricultural holdings and forest land),

Measure: 'Restoring agricultural production potential damaged by natural disasters and introduction of appropriate prevention actions' - two sub-measures: 'Support for investment in preventive measures to limit the effects of probable natural disasters, adverse climatic events and catastrophic events' (support for investments that prevent damage caused to agricultural holdings by flood or heavy rainstorm) and the sub-measure 'Support for investments in the restoration of 
agricultural land and restoring agricultural production potential damaged by natural disasters, adverse climatic events and catastrophes' (support for investments that restore the production potential damaged by natural disasters),

Measure: 'Development of farms and economic activity' - five sub-measures: 'Bonuses for young farmers' (the beneficiary: a person aged 40 or under, with agricultural qualifications, who commences an agricultural activity for the first time or runs a farm No longer than 12 months before submitting the application); the sub-measure 'Restructuring small farms' (the objective: improvement in competitiveness and increasing profitability of small farms through an increase in the economic size of the farm, resulting mainly from the change in the profile of agricultural production); the submeasure 'Bonuses for starting up non-agricultural activities' (the objective: diversification of activities in rural areas); the sub-measure 'Development of entrepreneurship - development of agricultural services' (the objective: creating conditions for competitive and modern agriculture and for the diversification of economic activity in rural areas, thus contributing to sustainable socio-economic development of rural areas); the sub-measure 'Payments for farmers transferring small farms' (the objective: a permanent transfer of the farm to another farmer),

Measure: 'Basic services and village renewal in rural areas' - three sub-measures (the objective: improving living conditions in rural areas by providing access to basic services, including technical and cultural infrastructure, for people inhabiting rural areas, and supporting local development); the sub-measure 'Support for investments in the creation, improvement or expansion of all types of small scale infrastructure, including investments in renewable energy and energy saving'; the sub-measure 'Studies and investments associated with the maintenance, restoration and upgrading of the cultural and natural heritage of villages' (operations related to preservation of monuments and traditional architecture); the sub-measure: 'Support for investments in the setting-up, improvement or expansion of basic local services for the rural population, including leisure and culture, and the related infrastructure' (investing in recreation and cultural facilities and the related infrastructure, as well as operations associated with investments in marketplaces or building structures for the promotion of local products and services),

Measure: 'Agri-environment-climat' (the objectives: sustainable fertilizer management, soil erosion prevention, soil and water protection, preservation and protection of valuable natural habitats and endangered plant and animal species, protection of endangered genetic resources of crops and farm animals as well as landscape diversity protection),

Measure: 'Organic farming' (the objective: restoring, protecting and enriching ecosystems associated with agriculture and forestry, preventing soil erosion and improving soil management).

\section{Financing the Rural Development Programme}

The second pillar of the CAP is financed mainly from the budget of the European Agricultural Fund for Rural Development (EAFRD), which was established by Council Regulation (EC) No 1698/2005 (6). It aims to improve the effectiveness of measures under the rural development policy and to simplify its implementation. It makes it possible to improve the management and control of the rural development policy during the MFF 2007-2013. The regulation defined the general principles of Community support for rural development financed by the EAFRD. It also determined the objectives of the rural development policy, stressing that it should contribute to:

- increasing the competitiveness of the agricultural and forestry sectors,

- improving the natural environment and landscape, 
- improving the quality of life in rural areas and increasing support for diversification of economic activity.

The EAFRD budget amounted to EUR 96.3 billion under the MFF 2007-2013, i.e. $20 \%$ of the funds allocated to the CAP in this period. The fund is used by all EU countries in proportion to the position of the agricultural sector in their economies and existing needs. In the MFF 2014-2020, the fund has a comparable amount of EUR 99.6 billion, which is supplemented by EUR 61 billion from public funds of the Member States (the so-called own contribution). The largest beneficiaries of these funds are (in billion EUR): France (11.4), Italy (10.4), Germany (9.4), Poland (8.7), Spain (8.3) and Romania (8.1) (Commission, 2015).

The share of the CAP in the MFF 2014-2020 is distributed as follows: EUR 312.7 billion ( $29 \%$ ) is earmarked for market-related expenditures and direct aids (Pillar I), and EUR 95.6 billion (9\%) for rural development (Pillar II). Essentially, we are dealing here with two parallel phenomena: a decrease in the share of expenditures allocated for financing the CAP (currently $38 \%$, while in the early 1980 s almost $70 \%$ ), and simultaneously a slow increase in funds directed to the implementation of the second pillar of the CAP (Skulimowska, 2013, EU agriculture, 2015).

Being the largest net beneficiary, Poland received a total of EUR 147.6 billion from the EU budget, of which EUR 92.5 billion for the cohesion policy and 47.6 billion for the agricultural sector in the years 2004-2018. The distribution of funds within the agricultural sector was as follows: Pillar I EUR 30.2 billion, and Pillar II - EUR 17.4 billion.

\section{Conclusions}

In EU policy, the agricultural sector has played a significant role from the beginning. As part of successive reforms, increasing attention was paid to establishing the second pillar in the form of a rural development policy. Strengthening of this pillar within the CAP is inevitable in the face of the intra-EU and global challenges. The need for further complementing of the rural development policy after 2020 is confirmed, for example, by the recommendations specified in 2017 in the Cork 2.0 declaration. Much space has been devoted there to the needs for sustainable development, protection of natural resources and ensuring generational renewal. Moreover, a number of new priorities have been identified, with a particular focus on value chains in rural areas in the fields of clean energy, the emerging bioeconomy sector as well as the circular economy or ecotourism.

\section{Bibliography}

1. Commission Delegated Regulation (EU) (2015) No 2015/791, of 23rd May 2015 Amending Annex I to Regulation (EU) No 1305/2013 of the European Parliament and of the Council on Support for Rural Development by the European Agricultural Fund for Rural Development.

2. Decyzja Rady z 20 lutego 2006 r. w sprawie strategicznych wytycznych Wspólnoty dla rozwoju obszarów wiejskich na lata 2007-2013 (2006) (Council Decision of 20 February 2006 on Community Strategic Guidelines for Rural Development - Programming Period 2007 to 2013) 2006/144/WE

3. Drugi filar Wspólnej Polityki Rolnej: polityka rozwoju obszarów wiejskich (2019) (Second Pillar Of The Cap: Rural Development Policy) http://www.europarl.europa.eu/ftu/pdf/pl/FTU_3.2.6.pdf (Access: 31.01.2019.).

4. EU Agriculture Spending,(2015) Agriculture and Rural Development http://ec.europa.eu/agriculture/index_en.htm (Access: 1.01.2019.).

5. Hardt Ł.,(2003) Implikacje reformy Wspólnej Polityki Rolnej dla polskiego rolnictwa i obszarów wiejskich, UKIE, Warsaw, 2007; Ocena reformy WPR uzgodnionej w Luksemburgu 26 czerwca 2003 r. z perspektywy Polski (Evaluation of the CAP Reform Agreed in Luxembourg on June 26, 2003 from Poland's Perspective), Foundation of Assistance Programmes for Agriculture FAPA, Warsaw

6. Europejski Fundusz Rolny na rzecz Rozwoju Obszarów Wiejskich (2015) (European Agricultural Fund for Rural Development), European Commission, Brussels

7. Oleszko-Kurzyna B., (2010) Rozwój obszarów wiejskich jako priorytet wspólnej polityki rolnej Unii Europejskiej (The Development of Rural Areas as a Priority of the European Union's Common), Annales Universitatis Mariae Curie-Skłodowska, Vol. XLIV, Sectio H., pp. 103-105. 
8. Polityka UE w zakresie rozwoju obszarów wiejskich na lata 2007-2013 (2008) (EU Policy on Rural Revelopment for 2007-2013), Fact Sheet, Luxembourg: Publications Office of the EUp. 4.

9. Program Rozwoju Obszarów Wiejskich przygotowany przez Komisję Europejską i Ministerstwo Rolnictwa $i$ Rozwoju Wsi RP na lata 2014-2020, (2018) (Rural Development Programme 2014-2020), Warsaw

10.Skulimowska M., (2013) Sprawozdanie na temat unijnego budżetu na lata 2014-2020 (Report on the EU Budget for 2014-2020) Report 120/2013, Brussels, December https://www.senat.gov.pl/download/gfx/senat/pl/defaultopisy/296/5/1/120.pdf (Access: 30.12.2018).

11. Wieliczko B., (2006) Polityka Unii Europejskiej wobec obszarów wiejskich (The EU's Rural Development Policy), "Institute of Agricultural and Food Economics", No 134, Warsaw p. 12, 42.

12.Zrozumieć politykę Unii Europejskiej - Rolnictwo (2014) (Understand the Policy of the European Union Agriculture), Luxembourg: Publications Office of the EU 